\title{
Könyvszemle
}

SIPOS JÚLIA GONDOZÁSÁBAN

\section{TUDOMÁNYOS MESÉK EGY DIGITÁLIS KORNAK}

Sokat gondolkozom azon, hogy a 21. század eleje vajon elhozta-e a papirkor végét. Az 1990-es évek elejétől a könyvek és folyóiratok, de még az állami nyilvántartások világában is rohamosan terjednek a digitális módszerek. Gondolta volna bárki 2000-ben, hogy 2020-ra egy adóbevallást ki lehet tölteni tinta és papír nélkül? Valamennyire azért vannak fenntartásaim ebben a kérdésben: ha lehet, még mindig papírra nyomtatott dolgokat szeretek olvasni. S azt sem tudom elfelejteni, hogy saját házi könyvtáramban van kétszáz éves kémiakönyv, amit minden további nélkül tudok olvasni, ugyanakkor a húsz évvel ezelőtt készült számítógépes állományok újra megnyitása sokszor ütközik akadályokba. Persze ettől még a digitális formátumok hatalmas előnye a másolatok készítése, illetve a terjesztés sebessége terén teljesen nyilvánvaló.

Minden bizonnyal a kor szavát halotta meg az Akadémiai Kiadó, amely Betekintés címmel tudományos ismertterjesztő könyvsorozat publikálását kezdte meg a Magyar Elektronikus Referenciamü Szolgáltatás (MeRSZ) oldalain. Az első nyolc kötet már e sorok írása idején is elérhető. Saját fenntartásaim azért annyira nem voltak súlyosak, hogy a nyolc mü egyikét ne én jegyezzem. E könyvismertetés hátralévő része természetesen arról a hét könyvröl szól, amelynek megalkotásában nem vettem részt.

A MeRSZ-en ma már hatszáznál is több könyv található meg, jelentős részük az Akadémiai Kiadó korábban, papíralapon is megjelent mủveinek új, digitális kiadása. Ezekben sok olyan lehetőség nyílik meg, amely egy papíralapú vagy akár még konvencionálisabb elektronikus (epub, mobi...) formátumban is teljességgel lehetetlen vagy igen nehézkes: a művekben akár összetett keresőeljárások is használhatók, jegyzetek készíthetők, bekezdésszinten hivatkozhatók, internetkapcsolattal bárhol hozzáférhetők, multimédiás elemeket és kattintható webes hivatkozásokat tartalmazhatnak és a Wikipédiához hasonlóan folyamatosan frissíthetők. A MeRSZ-en megjelenő könyvek is ISBN és DOI számot kapnak, illetve bekerülnek a Magyar Tudományos Mủvek Tárába.

A kizárólagosan elektronikus felületen publikálásnak persze vannak hátrányai is: ezek a múvek csak számítógépen, táblagépen vagy mobiltelefonon olvashatók, e-könyv-olvasón már nem, így például az én Kindle készülékemen sem. Nyomta- 
tott példány nem készül belölük, illetve jelenleg még a nagy elektronikus könyvforgalmazók (libri.hu, lira.hu, bookline.hu) oldalain sem lehet semmiféle utalást találni a könyvek létezésére. Ez a tény azonban elsősorban a müvek terjesztését gátolja, s nem a hozzáférést: a mersz.hu szolgáltatásra a magyar felsőoktatási intézményeknek központi forrásból van előfizetésük, így bármely egyetemi dolgozó vagy hallgató olvashatja őket, s ennek kiterjesztése a közoktatási intézményekre jelenleg folyik (sajnos nem túl gyorsan). Természetesen egyénileg is bárki előfizető lehet.

A Betekintés sorozat alapvető célja, hogy az olvasót tömören és élvezetes stílusban bevezesse egy-egy szükebb szaktudományba. A legkevésbé sem véletlen a kiadó által választott jelszó: szerethető tudomány. Egy-egy kötet teljes terjedelme 120-150 nyomtatott könyvoldalnak felel meg. Elsősorban a szerző élettapasztalatára alapozva, időnként felvállaltan szubjektív módon érzékelteti a terület lényegét, mélységét, összetettségét és fontosságát a közös emberi tudás szempontjából. A tartalom tudományos pontosságára és naprakészségére a garanciát a tudományos ismeretterjesztésben igen járatos szerzők személyisége teremti meg. Ketten közülük, Falus András és Ritoók Zsigmond a Magyar Tudományos Akadémia rendes tagjai. A kétnyelvü szótárak készítésének rejtelmeibe bevezető Magay Tamás a Károli Gáspár Református Egyetem angol tanszékének, a European Association for Lexicography és a Magyar Tudományos Akadémia Szótári Munkabizottságának egyik alapítója, a tudományterület legnagyobb szaktekintélyű hazai mủvelője. A filozófia képzetes terébe bepillantó Hévizi Ottó filozófus és eszmetörténész, a Bölcsészettudományi Kutatóközpont tudományos tanácsadójaként dolgozik. A nyelvtudományról író Nádasdy Ádám számos rádióműsorban, újságcikkben, könyvben népszerüsítette már az emberi nyelvek általános vonásairól szerzett ismereteket.

Talán nem véletlen, hogy a müvek közül kettő is a digitális információ tudományokra gyakorolt hatását helyezi a középpontba. Azt gondolhatnánk, hogy a reneszánsz és a barokk irodalomról felhalmozott tudásunkra a digitális módszerek elterjedésének vajmi kevés hatása lehet. Ennek ellenkezőjét bizonyítja Maróthy Szilvia irodalomtörténész, a Digitális Bölcsészet címü folyóirat felelős szerkesztője, aki bemutatja, hogy a számítógépek megjelenése és elterjedése számos új lehetőséget nyitott a bölcsészettudományi kutatásokban is. A fokozatosan bekövetkező változások során a régebbi, hagyományközpontú gondolkodást az adatközpontú, formálisabb módszerek váltották fel, illetve egészítették ki. A szerző igen meggyőzően támasztja alá azt a nézetet, hogy a számítógépes elemzések bevonása a kutatásba a legjobb, ami a bölcsészettudományokkal történhetett.

Az első mondatomban feltett kérdésre (a 21. század eleje elhozta-e a papirkor végét?) nem kisebb szaktekintély, mint Kokas Károly próbál meg válaszolni. A szerző a Szegedi Tudományegyetem Klebersberg Könyvtárának informatikai és információs föigazgató-helyettese, a teljes magyar tudományos világ életét 
megkönnyítő Magyar Elektronikus Könyvtár, majd az Elektronikus Információszolgáltatás (EISZ) egyik megálmodója. A könyvtár fogalma éppen alapjaiban alakul át napjainkban. A több mint kétezer éve Alexandriában alapított Muszeion óta a könyvtár elsősorban az a fizikai hely volt, ahol a könyveket tárolják. A digitális korban viszont értelmét vesztette a példányszám vagy a nyitvatartás fogalma, illetve a nyomdatechnika már nem jelent lényegi korlátozó tényezőt a müvek elkészítésében. A könyvek tulajdonlása lényegtelenné vált, a hozzáférés vette át a főszerepet. A könyvtár fizikai helytől, időtől és elérési módtól független eszménnyé, egyfajta platóni ideává vált, amelyben digitális ökoszisztémák alakulnak ki, korábban elképzelhetetlenül összetett lehetőségekkel, az olvasói igényekhez azonnal illeszkedő kiszolgálással. Kokas Károly ezt az átalakulási folyamatot mutatja egyfajta időutazásra invitálva az olvasót, amely egyáltalán nem a jelenben ér véget.

Ebben a szellemben ajánlom mindenkinek a Betekintés címü digitális sorozat müveit. A könyvek olvasói nemcsak ismeretszerzési lehetőséget kapnak, de a szerzők egyben a tartalmas szórakozástatásról is igyekeztek gondoskodni.

(Betekintés. [Pomázi Gyöngyi sorozatszerkesztö]: Hévizi Ottó: Diaphoron. Különbözés; Maróthy Szilvia: Digitális bölcsészet; Lente Gábor: Ezeregynél is több molekula meséi; Kokas Károly: Kalauz a modern könyvtárak világába; Nádasdy Ádám: Kalauz a nyelvészi gondolkodáshoz; Ritoók Zsigmond: Pillantás az ókortudományba; Falus András: Sakk? Patt!; Magay Tamás: Zöldgallytörés, avagy minden, amit a szótárírásról tudni érdemes; https://mersz.hu/betekintes/)

Lente Gábor

Pécsi Tudományegyetem, Természettudományi Kar Általános és Fizikai Kémiai Tanszék 